\title{
The Words behind Images: A Critical Social Semiotic Approach toward Analyzing Advertising
}

\author{
Maryam Najafian (Corresponding author) \\ Department of English Language and Literature, Faculty of Foreign Language \\ Hezarjarib Street, University of Isfahan, Isfahan, Iran \\ E-mail: m.najafian56@yahoo.com
}

Saeed Ketabi

Assistant professor of Applied Linguistics

Department of English Language and Literature, Faculty of Foreign Language

Hezarjarib Street, University of Isfahan, Isfahan, Iran

E-mail: ketabi@fgn.ui.ac.ir

Received: August 29, 2011 Accepted: September 27, 2011 Published: December 31, 2011 doi:10.5296/ijl.v3i1.880 URL: http://dx.doi.org/10.5296/ijl.v3i1.880

\begin{abstract}
This study was an attempt to investigate the application of Fairclough's (2003) Critical Discourse Analysis (CDA) approach and Social Semiotic Approach (SSA) proposed by Kress and van Leeuwen (2006) in analyzing ads discourse i.e. an approach that combines textual analysis with semiotic analysis in studying advertising. This combined approach was checked in two sample ads extracted from 'Time' magazine (2000, 2001). As results, two points emerged based on this study. The first was that advertising is a crucial factor in the dissemination of ideological values in any social discourses. The second point was that this discourse is not in any sense neutral. This is mediated, meaning that whatever aspects of social life are represented in the advertising pass through the particular linguistic (cohesion, disjunctive syntax, modality) as well as social semiotic resources (words, images and colors).
\end{abstract}

Keywords: Print advertising, Critical discourse analysis, Ideology, Social semiotic analysis 


\section{Introduction}

Advertising has long been a subject of several studies in different disciplines such as mass communication, marketing, sociology, cultural anthropology, social psychology, semiotics and cultural studies. Ahmed (2000: 11) believes that "whether from a quantitative, qualitative or interpretive perspective, whether a researcher follows the modern social scientific approach, critical theory perspective or postmodernist approach, analysis of advertising and other media content is of growing importance." Advertising for Cook (1992) is a prominent discourse type in all contemporary societies. For him, the important distinguishing feature of advertising (henceforth ad) discourse is its function, which is usually to persuade people to buy a particular product. But, this is not the only function.

Saren et al. (2007: 128) claim that, "adverts utilize a pre-existing referent system of meaning, because the product, prior to signification in the advert, has no meaning." Goldman (1992: 2) reads ads socially by identifying advertising as a key institution in "producing and reproducing the material and ideological supremacy of commodity relations." He calls this system 'commodity hegemony'; because, "they reproduce a sense of commodity relations as a natural and inevitable part of the lives of different individuals" (Saren, et al 2007, p.129). According to Durant \& Lambrou (2009: 93),"advertising conveys information, so that consumers know what is available, who makes it, and where and how they can get it." As Williamson (1978) points out advertising ask readers to see themselves and the worlds ideologically. Baren \& Davis (2008) state that, advertisements frame issues for readers; hence, they construct their perceptions of the social world.

Goatley (2000) investigated the obvious and less obvious ideological strategies in and behind advertisements and presented some important aspects of consumerist ideology used by copywriters. Bloor \& Bloor's (2007) 'the Practice of Critical Discourse Analysis' seeks to develop readers' awareness of language and ideology provides practice in analytic skills applied to various type of discourse such as advertising.

This study is based on the analytic paradigm of Critical Discourse Analysis (CDA) described by Fairclough $(1989,1992,1995 a, 1995 b)$ who suggests that the analysis of media discourse should be multidimentional in the sense that texts must be related to the discourse practice and to the social practice of which they are part and Social Semiotic Analysis (SSA) introduced by Kress and van Leeuwen (2006). The sample used in the detailed discourse analysis consists of two ads extracted from 'Time' magazine. The rational for choosing 'Time' magazine is that it is popular mainstream magazine which is being published for more than 80 years and still is available in most newsagents.

Najafian's (2010, p.123) article entitled 'Print Advertising and Globalization: a Critical Approach' suggests that advertising is a crucial factor in the global dissemination of ideologies.

In this study, Fairclough's concept of ideological analysis of texts would be combined with analyzing the semiotic aspects of these ads and their inter-discursal features according to the Social Semiotic theory proposed by Kress and van Leeuwen (2006). Fairclough (2003) states 
that textual analysis is a resource for social research which can enhance it provided that it is used in conjunction with other methods of analysis. 'Discourse' is associated with a particular way of conceptualizing and researching language, as well as other semiotic forms such as visual images. According to Williamson (1978, p.12), "ads are message systems designed to organize perceptions and create structures of meaning." Hence, CDA allows us to incorporate textual analysis within social analysis of advertising.

Goldman (1992) states that:

Advertising involves a commercially viable language of appearances and images in which commodity relations systematically penetrate and organize cultural meaning. Not only are commodities joined to signs, commodities get produced as sign and signs become produced as commodities.

This study would critically examine the conventions of persuasive text, using textual devices as well as social semiotic resources as paradigms to make up a rubric that advertisers can use in their own work. Knowing how to unmask and reveal implicit and hidden meanings behind ads seems to be useful for increasing critical language awareness. Use of proper features in print ads may also add the trustability of ads. And, deliberate interplay of lexical items that are collocationally related or even just boldly repeated, can be created another ideological level of meaning that supersedes the sense of each word in isolation. More important, the results of this study may help us as readers of ads rethink and refine our ideas and enhance our critical awareness to read between the lines, in order to get a sense of what discursive/ ideological position, what interest, may have given rise to a particular advertisement. Fairclough (1993: 135) defines CDA as follows:

Discourse analysis which aims to systematically explore often opaque relationships of causality and determination between (a) discursive practices, events and texts, and (b) wider social and cultural structures, relations and processes; to investigate how such practices, events and texts arise out of and are ideologically shaped by relations of power and struggles over power; and to explore how the opacity of these relationships between discourse and society is itself a factor securing power and hegemony.

Needless to say, every advertiser may be under his/her own ideological constraints as well as ideological constraints imposed on them by dominant power relations in society. Van Dijk (1995: 17) states that, "ideologies are typically, though not exclusively, expressed and reproduced in discourse and communication, including non-verbal semiotic messages, such as picture, photographs and movies." Advertising may have a specific contribution to the construction of a global village, the partial understanding of the external worlds. The textual analysis proposed by Fairclough addresses a diverse range of features of texts such as direct address to audiences, modality, nominalization, passive voice, vocabulary and rhetorical and persuasive features of texts.

Durant \& Lambrou (2009: 214) in Language and Media, state some of the questions proposed by Fairclough which ought to be an objective of media and language education to 
ensure that students can answer them about any media text:

i) How are texts of this sort produced, and in what ways are they likely to be interpreted and used?

ii) What wider socio-cultural processes is this text a part of, what are its wider social conditions, and what are its likely effects?

To probe into aforementioned problem, the present study would address the following research questions:

i) What linguistic and social semiotic resources are used by advertisers in these two global advertisements?

ii) Is there any ideological consideration in using linguistic and social semiotic resources in advertising discourse?

In this research, advertising is an independent variable which can through ideology (second variable) have impact on individual and society structure by making social and political evolutions via selecting specific textual as well as semiotic devices.

\section{A Critical Social Semiotic Approach in Analyzing Ads}

\subsection{Using the Concept of Critical Discourse Analysis for Ads Analyzing}

Fairclough (2003) claims that each discursive event has three dimensions or facets: (i) it is a spoken or written language text; (ii) it is an instance of discursive practice involving the production and interpretation of text; and (iii) it is a piece of social practice. Fairclough (1989: 10) identified his approach, not as just another method of language study, but as "an alternative orientation." What he called "a social theory of discourse" (Fairclough, 1992a: 92) was an attempt to "bring together linguistically-oriented discourse analysis and social and political thought relevant to discourse and language." Fairclough (1992) states that, the focus in analyzing discourse as a text is on form and meaning, which includes analyses of generic structure, text dialogic organization, cohesive relations between sentences and relations between clauses in complex sentences as well as the grammar of the clause and vocabulary. He continues that, the analysis of discourse as a discursive practice involves the processes of text production, distribution and interpretation (or consumption). And, texts are elements of social events, and orders of discourse are elements of social practices.

Simpson \& Mayr (2010: 54) state that, the 'text' dimension involves the analysis of such features as:

- Choices and patterns in vocabulary (e.g. wording and literary devices);

- Grammar (e.g. the use of modal verbs);

- Cohesion (e.g. conjunction).

Fairclough's concept of the analysis of discursive practice focuses on the features of the text, but 'discourse refers to the whole process of social interaction of which a text is just a part' (Fairclough, 1989: 13); hence, this research combines the dimension of visual analysis proposed by Kress and van Leeuwen (2006) to that, of which the text and image are products, 
and the process of their interpretation, for which the text and image are resources. Kress \& Hodge (1979) state that discourse cannot exist without social meanings, and that there must be a strong relation between linguistic and social structure. Thus, linguistic analysis is only one part of discourse analysis, which also incorporates analyzing of social resources. The social semiotic analyzing interlocks with an advertisement text and CDA can act as a means to enrich our understanding of concepts that are pivotal in such analysis.

\subsection{A Social Semiotic analysis of ads}

"Semiotics and Social Semiotics differ in that the latter in particular explores the correspondence and interconnection between social practices and discourse" (Meinhof 2004: 263, cited in Yates \& Yates). Meinhof believes that social semiotics take the old semiotic path from sender to message to receiver and expands it into multidimensional interactive bodies of relations (ibid.).

Kress and van Leeuween (2006) introduce the existence of 'a visual code or grammar of visual design'. They believe that both visual structures and verbal structures can be used to express meanings drawn from common cultural sources. According to them "Like linguistic structures, visual structures point to particular interpretations of experience and forms of social interactions" (ibid.: 2). They believe that, by employing different modes, design, production and interpretation can construct meanings. The creator and the viewers (interpreters) are the participants in the grammar. But, the interpretation way used by viewers cannot be always controlled by the creator.

Baren \& Dennis (2008) point out that in social semiotics, viewers are indeed active, but they are not necessarily very aware of what they do. And, when dealing with critical social semiotic theory, the microscopic details has much to say about the macroscopic one in the larger social order (ibid.). Images contain modality of signs which make interpretation of each sign possible according to specific cultural and ideological norms. The main aim of social semiotic analysis is to understand how readers and viewers make sense of advertising messages. According to Kress (1988: 261), "social semiotics concerned with the social meanings constructed through the full range of semiotic forms, through semiotic texts and semiotic practices, in all kinds of human society at all periods of human history."

According to Jewit \& Oyama (2001: 134), "social semiotics analysis of visual communication involves the description of semiotic resources, what can be said and done with images (and other visual means of communication) and how the things people say and do with images can be interpreted." Kress (2010: 59) states that in a social-semiotic multimodal account of meaning, all signs in all modes are meaningful. A social-semiotic theory tends to general principles of representation: to modes, means and arrangements. Social semiotics is able to say something about the function of the modes (writing, image, color and facial expression) in the multimodal text; about the relation of these modes to each other; and about the main entities (ibid.). According to Kress (2010: 54) "the focus on sign-making rather than sign use is one of several features which distinguish social-semiotic theory from other forms of semiotics." Based on his definition: 
In a social-semiotic account of meaning, individuals, with their social theories, socially shaped, located in social environments, using socially made, culturally available resources, are agentive and generative in sign-making and communication (ibid.).

Bignell (2002) states that, "photographs used in print advertisements work as a system of signs that gives form and meaning to consciousness and reality." According to van Leeuwen (2005: 8), "a good starting point for studying aspects of visual communication is to consider that there are two verbal and visual modes of communication in print advertising with complex interaction between them."

Najafian \& Ketabi (2011) investigated the usefulness of a social semiotic approach proposed by Kress and van Leeuwen (2006) in analyzing advertising discourse to achieve the aim of uncovering the ideology behind choosing different resources (verbal and non verbal). Their study revealed that social semiotic reference occupies a pivotal point in the relationship between advertising discourse and ideology. The image, word and color seen in this way as the product of social practices, are just three of the many semiotic modes through which social meanings of advertisements are coded.

It can be conceived that the linguistic and visual choices made by ad producers are not accidental at all. CDA can uncover the ideologically-laden choices in this particular discourse. In this way, the present study adopts the systemic functional approach of Michael Halliday (1994), namely that a full theory of communication will need to represent meanings about actions, states, events in the world, the ideational function; to represent meanings social relations of those engaged in communication, the interpersonal function; and have the capacity to form texts with all semiotic entities which have internal and external coherence, the textual function. The critical study of print ads is to improve individual's control over the messages they send and receive. Critical awareness is seen as a skill which can be improved.

\section{A Text- Linguistic Approach toward Analyzing Advertising Discourse}

The sample used in the detailed discourse analysis consists of two ads (see Figure1 and Figure2) extracted from 'Time' magazine. In social semiotics "texts are both the material realization of systems of signs, and also the site where change continually takes place" (Hodge and Kress 1988: 6). For social semiotics, the two terms 'text' and 'discourse' represent complementary perspectives on the same level of phenomenon. Both text and message signify the specific social relationships at the moment of their production and reproduction (ibid.).

According to Jefkins (1994), the first specific characteristic of print ads is revealed in the headline. Rowse \& Fish (2005: 145) state that "the headline is often the most conspicuous part of the advertisement and is therefore the thing that naturally catches the reader's eye in a hasty glance at the page." They summarize the function of headlines as follows:

i) to attract attention;

ii) to arouse interest;

iii) to make the advertisement more attractive and readable. 
Headlines are "probably the most important and the most used mechanical means of attracting attention" (ibid.). Lennon (2004: 84) believes that headline acts to express indirectly the advertiser's attitude to the issue and propose the attitude the readers should adopt. According to Maliszewski (2010: 171) "the more intriguing the language of a headline, the more provocative and original, the better it is memorized by the potential customers."

Table 1. Headlines. Summarizing the product functions and its characteristics

\begin{tabular}{|c|l|}
\hline Source & References to the most important items of information \\
\hline $\begin{array}{c}\text { OMEGA ads in 2000 } \\
\text { OMEGA ads in 2001 }\end{array}$ & $\begin{array}{l}\text { The OMEG Bond's Choice } \\
\text { making }\end{array}$ \\
\hline
\end{tabular}

Because one of the main characteristics of the headline may be that it orients the reader to process the text in a pre-determined direction, the headlines analyzed may give the preferred positive meaning on the subject discussed. It is believed that, headline summarizes the central action. Perhaps, a key feature of ads headline is to summarize the promotional activities and characteristics of organizations, their products or services. A shown in Table 1, there is no explicit praise in the headlines, but there are short statements with categorical claims about the promotional activities/characteristics of the organization.

In advertising discourse, headlines may represent what advertisers construe to be the most important items of information. A good headline may give a chance to grab the audiences' attention, and cause them to eagerly read the rest of ads copy. The headline, James Bond's Choice, in this ad interacts with the image, the body copy, which takes up the bottom part of the ad with the product itself ( This typically suave greeting..... is arguably one of the most easily recognized lines...., OMEGA has built up a lasting and life-saving relationship...., and is proud to be Band's choice ... .). A closer look at this ad reveal that it employs some widely used linguistic features in advertising, namely disjunctive syntax, cohesion and modality.

\subsection{Disjunctive Syntax}

According to Delin (2000: 129), "another strategy to mimic a conversational style in ads is the use of disjunctive syntax"; that is the use of sentences without verbs or subjects, or sentences consisting of one or two grammatical elements only. Here the headlines, 'James Bond's Choice' and 'The OMEGA CO-Axial Escapement, a Revolution in Master Watch making', would fall into this category.

\subsection{Cohesion}

The cohesion devices used in these two ads falls into two categories; namely over lexicalization and lexical cohesion.

\subsubsection{Over-lexicalization: Promotional vocabulary}

A single instance of a lexical cohesive relationship between two words is usually referred to as a lexical link (Ellman \& Tait, 1998; Hoey, 1991; Morris \& Hirst, 1991). Sequences of lexical chains in text normally produce lexical cohesion. Halliday and Hasan (1976) first 
introduced the term 'chain' which denotes a relation where an element refers to another element, and in turn refers to another element and so on. According to Morris and Hirst (1991), lexical chains are sequences of related words in text. The most direct and obvious form of lexical cohesion is the repetition of positive adjectives, such as successful or of (the highest) quality, which explicitly evaluates the subject discussed. The use of synonymous adjectives and other direct references to success, such as leading, most easily recognized, lasting, life-saving, proud, typically, arguably in ad1 and positive words such as, innovation, new, ensure, totally, greater accuracy in the ad 2 contribute to the co-referentiality of the success of an organization, its products or services. In Table 2, the typical examples are presented for each of the ads analyzed.

Table 2. Lexical Cohesion. References to the success of an organization, its products or services

\begin{tabular}{|l|l|}
\hline Source & \multicolumn{1}{c|}{ References to success } \\
\hline OMEGA ads in 2000 & $\begin{array}{l}\text { This typically suave greeting..... is arguably one of the most } \\
\text { easilyrecognized lines....., OMEGA has built up a lasting and } \\
\text { life-saving relationship....,.,and is proud to be Band's } \\
\text { choice ... }\end{array}$ \\
\hline OMEGA ads in 2001 & $\begin{array}{l}O M E G A \text { presents an innovation that redefines the entire } \\
\text { theory of mechanical watchmaking. Today, OMEGA breaks the } \\
\text { mould with a totally new design,... . The new design is based } \\
\text { on... . It ensures greater accuracy over time }\end{array}$ \\
\hline
\end{tabular}

The ads analyzed use vocabulary which has to do with promotion. According to Cook (1992) and Jefkins (1994), headlines' key characteristic is the use of positive words. As Fowler (1985: 65) argues, vocabulary might be seen as a map "of the preoccupations of a culture [...] detailed systems of terms develop for the areas of expertise, the features of habitat, the institutions and relationship, and the beliefs and values of a community."

The above table shows the ads discourse analyzed, aimed at providing a broad overview of the kind of discourse strategies that advertisers can and do exploit to make the products globally acceptable. Advertisers try to form a positive image of the organization or positive publicity in ads and among their readers; and this seems to be the basic function and effect of them.

\subsubsection{Lexical Cohesion}

Cohesion is a property that contributes to the creation of textual coherence (Hoey, 1991). Widdowson (1978: 31) defines cohesion as "the overt linguistically signaled relationship between propositions", concerns the ways in which the words in a text are mutually connected into a sequence. Coherence, however, has been defined as the property of 'unity', of 'hanging together' (Hasan, 1984) which concerns the ways in which the configuration of concepts and relations that underlie the surface text are mutually accessible and relevant. Therefore, the surface cohesion of a text predisposes a reader to search for an underlying 
structure of relations that makes a text coherent. Lexical cohesion as the single most important cohesive tie used in a text (Hoey, 1991) therefore provides the discourse analyst with a key to unravel the potential ideological construction that underlies a text.

The repetition of a lexical item is the most direct form of lexical cohesion (Halliday, 1994). Moreover, Jefkin (1994) states that, the repetition of the name of the organization and the brand name throughout the text is one of the main rules of copywriting in advertising. In this way, lexical cohesion transcends its cohesive role as textual linker and assumes a role in the ideational function of language, re-shaping and re-conceptualizing meaning and experience and leads to the global images of products. Now, let's consider the sample data from the view point of lexical cohesion. Table 3 shows the use of repetition in these two ads.

Table3. Repetition of the company's name

\begin{tabular}{|l|l|}
\hline Ad1 & \multicolumn{1}{|c|}{ Ad2 } \\
\hline OMEGA has built up a lasting and.... & $\begin{array}{l}\text { The OMEGA Co-Axial Escapement } \\
\text { OMEGA presents an innovation } \\
\text { Today, OMEGA breaks the mould with a } \\
\text { totally new design }\end{array}$ \\
\hline
\end{tabular}

It could be seen that in the ad2, the name of the company is repeated. In the ad 2, lexical patterning plays an even greater and more salient role in promoting the product globally, perhaps because its promotional nature is harder for the reader to recognize.

\subsection{Modality}

Fairclough (2003: 166) states that, "modality choices in texts can be seen as part of the process of texturing self-identity." According to Halliday (1994), "modality means the speaker's judgment of the probabilities, or the obligations, involved in what he is saying" (cited in Fairclough 2003: 165). The body copy in the first ad projects high modality, with the repetition of the verb 'is' in all the sentences. The modality here is an epistemic (Knowledge exchange), with the speech function of statement. High modality shows high level or degree of commitment to truth. It may enhance the trustability of the text. Halliday (1994) schematically categorizes modalized clauses, both epistemic and demotic, in terms of different levels or degrees of commitment to truth on the one hand and obligation/ necessity on the other. What follows is a more detailed semiotic analysis of ads discourse to further unravel the sort of promotional structures embedded within.

\section{Social Semiotic Analysis of Sample Ads}

In terms of social semiotic analysis, an attempt has been made in this article to critically examine the theory proposed by Kress and Leeuween (2006) for analyzing visual communication including images, words as well as choice of colors.

\subsection{Images}

Figure 1 shows OMEGA ad issued in 2000. In terms of contextual analysis and the medium 
of communication, the advertisement of OMEGA watch transmits messages not only from the written language but also from the visual medium. The primary signifier in this ad consists of the well dressed actor. It used graphological devices to provide information; the picture and the trade mark of the product also provide visual information to the readers. It consists of the image of one American famous actor, Pierce Brosnan, who played in everlasting film, 007. The advertiser has used the more recognized name of this actor as James Bond in this ad instead of his actual name, due to its then global popularity. The large picture of James Bond and the product occupies almost two thirds of the space and may give a clear image of the product. Hall \& Whannel (1964: 328) state that in ads specifically produced for upper class consumers the "images and the copy concentrate upon the feelings of luxury or the desirable status pictured, the product takes second place". In ad1 the represented image of the watch resembles the product in reality.

In the ad 2, only the image of the product can be seen which may be aesthetically pleasing. Hence, on a denoted level what could be said to be seen are this one image. According to Dyer (1986 p.130), since "denotation is not neutral or untouched by ideology", whatever image is being used some sort of meaning is attached that goes beyond the literal meaning. On the connoted level because it is not neutral it is set within society - the ad cannot simply "reflect ideology, it reworks it, thus producing new meanings' and 'this connotation process depends on our knowledge of the forms of ideology that advertisements employ" (Dyer 1986, pp. $129-130)$.

In the ad1, when seeing the caption James Bond's Choice and the images, the reader, knowing the sorts of codes used in advertising, would initially think that this ad is about watch. In ad2, the large picture of the product occupies one thirds of the space and gives a clear image of the product. As for the space, the advertiser has made an attempt to attract their readers by placing one image of watch in the centre of this advertisement. The taglines reinforce this idea as it is placed directly underneath the image in a contrasting black font. The title and the central images of the ad, may deduce the readership effectively to try it once. At the bottom of the advertisement, there is a trade mark of the product, under the name of the product. It is in a sharp red which may make it more obvious and attractive and give impression to the readers to remember the trade mark and get familiar with it in latter days.

\subsubsection{Placement of signs}

The placement of the image may be very important. In the first ad, one image of the watch is placed in the centre of this advertisement and above that one human image is endorsed. The large colored human image occupies three-quarters of the ad and a relatively small section is devoted to verbal signs. This may imply that this human image is the central means of conveying information. According to Kress (2010), it is functionally dominant in carrying major 'informational load' of the image. Again, for the second ad, the image of watch occupies three-quarters of the ad and no human image is endorsed. Hence, it may put different impacts on reader.

The first watch ad, by placing the photographed famous actor 'James Bond' above the product actively constructs a relationship between the man and the product. Beasley and Danesi (2002) 
believe endorsing ads by celebrities makes a product more reliable. This may occur by placing an iconic sign (the photographed man) and a linguistic sign next to each other. Bignell (2002: 34) states that, "It is this relationship between one sign and another which is important for the meaning of the advertisement."

\subsection{2 'Given' and 'New' in Advertising}

According to Kress \& van Leeuwen (2006), in any sequential structure, the element which is about to be said or shown is always 'New', not yet known. By contrast, what has (just) been seen, heard, discovered is, by comparison, now known, 'Given'. In the first ad image of man is 'Given'; because, it is an element of familiarity in this advertisement. The 'New', on the other hand, is represented visually: picture of one watch. Just in the case of reading the body copy or seeing the emblem in this ad the viewer can know the name of the watch. Once named and described verbally, the watch become 'Given'.

The second watch ad (see Appendix 2) itself is divided into a 'Given- New' structure: the text or headline above the image is divided into two parts; the word OMEGA is the 'Given' ('the OMEGA co-axial escapement watch...) accompanied by the words; co-axial escapement and one picture of the product offering the new information with the body copy.

\subsubsection{Visual Modality}

Kress and van Leeuwen (2006: 89) state that "as with linguistic modality, visuals can be of high modality or low modality." High modality in visuals means that things or people look 'realistic'_the way they would look if one saw them in real life. Based on this definition, both ads contain realistic photos of human image and the products. Hence, they have high modality in terms of using images. According to Kress and van Leeuwen (2006: 155), "the term modality comes from linguistics and refers to the truth value or credibility of (linguistically realized) statements about the world". But, modality is not restricted to language, and it was Kress and Hodge (1979) who first pointed out four decades ago that modality is a multimodal concept that can be applied to photographs or any kind of visual representation. They believe that modality expresses "affinity-or lack of it- of speaker with hearer via an affirmation of their affinity about the status of the mimetic system" (Kress \& Hodge 1988: 123). It is believed that, modality has direct relation with interpersonal structures of ads. Kress and Hodge (1988: 147) argue that "whoever controls modality can control which version of reality will be selected out as the valid version in that semiosis process".

Both ads contain decontextualized background with a greater focus on the images of photographed man in the first ad and the watch in the second ad perhaps to create a symbolic world. Hence, the background in two ads has low modality. Endorsing no human images (female or male) in the second ad may indicate that this product is usable by both men and women. Kress and van Leeuwen (2006: 155) believe that "modality is 'interpersonal' rather than ideational. It does not express absolute truths or falsehoods; it produces shared truths aligning readers or listeners with some statements and distancing them from others"(ibid.).

\subsection{4 'Ideal' and 'Real'}


The first advertisement displays an 'Ideal-Real' composition. The top part of the ad, the 'Ideal part', consists of the picture of a famous actor, a person to be ideal for people and they may like to be in his place and the bottom part provides the factual detail and a 'Real' picture of the product. In other words, the modality of the top and bottom part is not the same. The top picture shows what one would actually (high modality) like to be when they buy the product. It is placed in the 'Ideal'. The body copy also represents real information about the watch. The watch itself and the body copy are 'Real' part of this advertisement. In the case of the second advertisement, the watch on the top part of the ad as well as the body copy makes the 'Real' parts. It can be concluded that the viewers of this ad should imagine the 'Ideal' part in their mind themselves.

\subsubsection{Framing}

In the first ad, no significant 'disconnection' is observed between the photographed man and the watch image from the purview of framing. There is no separation between these two images through frame lines or pictorial framing devices. According to Kress \& van Leeuwen (2006: 203), "the absence of framing stresses group identity." No framing stresses the lack of separation between units of information. The more the elements of the spatial composition are connected, the more they are presented as belonging together, as a single unit of information (ibid.). The same applies to the second ad (see Appendix2) where no frame lines are between verbal and nonverbal signs and the color harmony create a strong relation between the 'Ideal' and 'Real'.

Much empty white space is around the first advertisement. Machin (2004) has suggested that this "use of space is more common in ads for men, connoting perhaps a minimalist form of interior design, in contrast with a more homely and 'feminine' physical design and layout" (cited in Simpson \& Mayr 2010, p.90).

\subsubsection{Size of Frame and social distance}

Kress \& Leeuwen (2006: 124) point out that "the choice of distance can suggest different relations between represented participants and viewers. 'Close personal distance' is the distance at which one can hold or grasp the other person and therefore also the distance between people who have an intimate relation with each other." They state that size of frame is defined in relation to the human body. In the case of ad1, the photographed man is depicted in a personal way and advertiser used the close shot (or 'close- up') which shows head and shoulders of the subject. If this was all we could see of him in reality, we could be close enough to touch him. Hence, it may make a relatively intimate relation between the image and the viewer. The visual system of size of frame derives from the 'proximics', as Hall (1964) calls it, of everyday face-to-face interaction. Kress and van Leeuwen (2006: 127) point out that "the system of social distance can apply also to the representation of objects and of the environment. Then, size of frame can be used for describing shots of objects and landscapes." In both ads, the image of the watch is shown at close distance, we would suggest, the object is shown as if the viewer is engaged with it as if he or she is using the watch.

\subsubsection{Power and Angle}


Human image in the first ad and the watch product in the second ad photographed from a low angle, as if having symbolic power over us. Low angle shows the power of represented participants in ads over viewers. According to Martin, "low angles generally give an impression of superiority, exaltation and triumph...; high angles tend to diminish the individual, to flatten him morally by reducing him to ground level, to render him as caught in an isurmountable determinism"(cited in Kress \& van Leeuwen 2006: 140). As a result, if the picture is at eye level, then the point of view is one of equality and there is no power difference involved. But, as mentioned by Kress and van Leeuwen, this is a matter of degree. In the first ad, the photographed man does not look straight on us. Here, the man is depicted as exercising symbolic power on us.

\subsubsection{The Image 'Act' and the 'Gaze'}

Kress and van Leeuwen (2006: 116) state that "there is a fundamental difference between pictures from which represented participants look directly at the viewer's eyes and pictures in which this is not the case." According to them when participants look at the viewer, vectors, formed by participants' eye lines, connect the participants with the viewer. Appendix 1 is an ad in which James Bond does not look directly at the viewer. Hence, contact may not be established. These kinds of pictures address the viewers indirectly. Here the viewer is not object, but subject of the look. Halliday (1985) calls this kind of image "an 'offer' in a sense that, it offers the represented participants to the viewer as items of information, objects of contemplation"(cited in Kress \& van Leeuwen 2006: 119).

\subsection{Words}

According to Kress and Hodge (1988: 8) "Social Semiotics begins its description with an account of the 'logonomic' system, that is, the social messages which govern the normal production and reception of the text." In this way, the context has to be theorized and understood as another set of texts. The sample ads contain texts on a large scale, displayed on a magazine. This indicates one set of logonomic rules immediately: the right to use this kind of ads is explicitly controlled by publication laws, and there are agencies which control the appearance of messages in such kind of global magazine. There exist discretionary powers which can determine both whether a text may appear here, and what kind of text may appear. In the ad1, the headline consists of three capital and bold words, James Bond's Choice, in order to perhaps draw receiver's attention and make them curious about what this advertisement mainly says and thus may lead the readers to go on reading without any conscious and arouse their curiosity and desire to know more about this product and finally may reach its goal to persuade the readers to buy it. Meanings are socially made, socially agreed and consequently socially and culturally specific. Seeing how the anchorage between the picture and the text directs us towards the 'correct' reading of the advertisement. The relay between the watch denoted iconically in the ad and the linguistic sign 'James Bond's Choice' makes it easy to see that this is a special watch product for men. According to Beasley \& Danesi (2002: 17), "the ultimate goal of creating an appropriate image for a product is to embed it into social consciousness."

In the ad2, as the title stands boldly in the top of the page, The OMEGA CO-Axial 
Escapement, a Revolution in Master Watch making, this is the image that the eye may initially drawn towards. Based on the theory of layout proposed by Kress and Leeuwen's (cited in Bell 1997, p. 193), this could also give the magazine ad "a sense of idealism, suggesting that the reader should aspire to attain the life and image referred to within the pages." In this advertisement of 'OMEGA', larger, capital and bold letters are used in the headline possibly to draw receiver's attention and make them curious about what this advertisement mainly is about. This may lead the readers to go on reading and arouse their curiosity and desire to know more about this product and finally may reach its goal to persuade the readers to buy it. Meanwhile, there is a compound word 'Co-Axial' in the headline, which could make the word more conspicuous among those big words and be distinguished from other words. This word seems to contain a special meaning which anchors the preferred reading for the reader - as the reader will presumably be familiar with different kinds of OMEGA watch. One image of Co-Axial escapement at the middle of the text could make the description of this watch more trustable and tangible for the readers. At the same time, the advertisement uses smaller-than-headline letters for the body copy. It seems to make it attractive, eye catching and clear for the readers. The body copy provides more information about the product and furthermore shows the advantages of the products and makes the headline more believable.

In the both ads, the trade mark is specially designed, which contains big letters. The last letter of the Greek alphabet $(\Omega)$ above the logo may show the long experience of the company as its name. The last part contains only one sentence which provides the website of 'OMEGA' company. The positive side of it may be that it makes the reader aware that a product or service is available and allows reaching a huge number of people in an unlimited geographic area. It can make this brand more trustable.

\subsection{Colors}

According to Kress \& van Leeuwen (2006: 229) "color is primarily related to affect", and Halliday and others (e.g. Poynton, 1985; Martin, 1965) see affect as an aspect of the interpersonal metafunction. They believe that color is used metafunctionally, and it is therefore a mode in its own right. Color may play an important role in the success of advertisements and it seems to be the first thing the receivers notice. From ideational perspective, "color clearly can be used to denote people, places and things as well as classes of people, places and things, and more general ideas" (Kress \& Leeuwen 2006: 229). "Again color is also used to convey 'interpersonal' meaning [...]. It can be and is used to do things to or for each other" (ibid.). It may show the 'personality' of a product which is often very difficult to articulate.

According to Kress (2010: 88), "most of us [...] have quite a strong sense of the meanings of color; which is to say that we could easily articulate what such meanings are." Blue is the predominant color in the first ad which is somewhat ironic given that the ad stress that the watch contains this color. The watch below the photographic picture may serve to reinforce this claim. In result, there may exist color coherence in the first advertisement. It seems that, the repetition of one color, black, is used to promote textual cohesion. Using the blue color in 
this ad also could represent ideational function; because, it is used to denote the special 'OMEGA' watch product as its image has the same color and signals its identity. Simpson \& Mayr (2010: 89) believe that "looking at what is hidden or made less important or what is enhanced (e.g. colors) can tell us about the world that is created for us." The golden and black colors are the dominant colors of the ad2, which in turn implies the ironic given that the absolute color of the product has golden result. One image of the product may enhance this claim.

According to Scollon and Scollon (2003: 91), as the same as language, visual images can convey cultural values and stereotypes. For instance, cultures have different "high modality" colors and colors may have political, social or even commercial indexical values. In the ad1, the authentic color may make the watch inviting. "In designing print ads, one of the decisions the advertiser must make is which color(s) to use as executional cues in the ads and typically, color decisions are based on intuition and anecdotal evidence" (Gorn et al. 1997). Colors are non-verbal signs. They may have symbolism and color meanings. As Bellizzi et al. (1992) state "choosing a particular color (or colors) is a difficult and subjective task, as there is little that can be classified as solid fact."

In the ad1, the man is dressed formally; wearing blue watch on his left hand and under his image is the same blue watch. Color, according to Lester (2000: 11) "attracts attention to a particular detail like no other visual attribute and is used to create specific associations with elements of nature". Much of the readers' reaction to the ad comes solely from looking at these two images, more specifically, from the image of the man as a very famous actor in the entire world.

All the words in the phrase, Die another Day, have been colored by red. It is believed that 'red' is a very emotionally intense color. It has very high visibility and brings text and images to the foreground. Advertisers may use it as an accent color to stimulate people to make quick decisions; perhaps it is a perfect color for 'Buy Now' or 'Click Here' buttons on Internet banners and websites. Walters et al. (1982) found a link between the color red and the felt excitement, and the color blue and the felt relaxation. This is consistent with the generally accepted view that red is an exciting color, whereas blue is relaxing (e.g., Tom et al. 1987). Both feelings of excitement and relaxation are pleasant and likely to lead to favorable attitudes. In the ad2, the authentic color can make the watch inviting and desirable. The golden brightness of the watch stands in contrast to the black of its background and thus may attract one's eyes toward it and make it the center of our attention with cheerful feelings. Black denotes strength and authority; it is considered to be a very formal, elegant, and prestigious color. It could give the feeling of perspective and depth. As mentioned above, red brings text and images to the foreground. Advertisers may use it as an accent color to stimulate people to make quick decisions.

\section{Conclusion}

As one underlying goal of this article was to combine and integrate insights from two traditions of CDA proposed by Fairclough (2003) and Social Semiotic Analysis (SSA) proposed by Kress and van Leeuwen (2006), we wish to conclude this paper with results 
that not only encapsulates the main argumentation of this analysis, but that also exposes the way interpretation does, can and should converge with concerns within the interpretative tradition in the studies of critical discourse processing of advertising. Here, the analysis focused on two dimensions of the communicative event in ads: text and image. Although this analysis has been far from exhaustive, it is suggested here that including the analysis of sign based on the approach proposed by Kress and Leeuween (2006) with Fairclough's approach could make it more comprehensive in analyzing ads. It was shown to be useful for analyzing ads, first, because text analysis alone could not identify the subject of the analysis, which tries to influence audiences for commercial benefit. The second reason is that the analysis of signs and images enable us to uncover the elements of promotion within ads discourse, something which linguistic analysis probably cannot reveal. The analysis of interdiscursivity of advertisements showed how advertisers through linguistic devices (cohesion, disjunctive syntax, and modality) as well as semiotic devices (images, words, and colors) incorporate discursive elements of promotion which are drawn upon within ads discourse. Discourse can be defined as an established way of understanding and representing the world. Some ways of conceptualizing would be dominant or hegemonic. The result of this study may have more implications for training ads translators, marketing students and linguists. More important, the results of this study may help readers of ads rethink and refine their ideas and may enhance their critical awareness to read between the lines, in order to get a sense of what discursive/ ideological position, what interest, may have given rise to a particular ads. Moreover, it would help the consumers to save time and select only the best products and services.

At last, two points could be emerged based on this study. The first is that advertising is a crucial factor in the dissemination of ideological values in any social discourses. The second point is that this discourse is not in any sense neutral. It is mediated, meaning that whatever aspects of social life are represented in the advertising pass through the particular linguistic as well as social semiotic resources.

\section{Acknowledgements}

The authors are deeply grateful to anonymous reviewers for their invaluable constructive comments on the earlier drafts of this article.

\section{References}

Ahmed, N. (2000). Cross- Cultural Analysis of Advertising from the United States and Indian. [Online] Available: www.dissertstion.com/library/1120842a.htm.

Baren, S, J \& Davis, K, D. (2008). Mass Communication Theory: Foundations, Ferment, and Future. [Online] Available: http://books.google.com/books?id=5TAebeoDnJ4C\&pg=PA330

Beasley, R. \& Danesi, M. (2002). Persuasive Signs: the Semiotic of Advertising. Berlin: Moutor de Gruyter. [Online] Available: http:// www. books. google.com/ books? id= as $1 \mathrm{r} 7 \mathrm{kC}$.

Bellizzi, J., Crowley, A. E., \& Hasty R.W. (1983) 'The Effects of Color in Store Design', 
Journal of Retailing, Spring, pp.21-43. and Hite, R. E. (1992) 'Environmental Color, Consumer Feelings, and Purchase Likelihood', Psychology and Marketing 9(5), 347- 363. http://dx.doi.org/10.1002/mar.4220090502

Bignell, J. (2002). Media Semiotics: an Introduction. Manchester: Manchester University Press. pp. 31-78. [Online] Available: http:// www. books. google.com/ books? id= MGom6ENJRLkI.

Bloor, T. \& Bloor, M. (2007). The Practice of Critical Discourse Analysis: An Introduction. London: Hodder education.

Burton, G. (2005). Media and society: Critical perspectives. New York: Open University Press.

Cook, G. (1992). The Discourse of Advertising. London: Routledge.

Delin, A. (2000). The Language of Everyday Life. London: Sage.

Durant, A. \& Lambrou, M. (2009). Language and Media. London: Routledge.

Dyer, G. (1986). Advertising as Communication. London: Routledge.

Ellman, J., \& Tait, J. (1998). Meta searching the web using exemplar texts: Initial results. In Proceedings of the 20th BCS-IRSG conference.

Fairclough, N. \& Wodak, R. (1997). Critical Discourse Analysis. In P. Simpson \& A. Mayr (Eds.), Language and Power. London: Routledge.

Fairclough, N. (1989). Language and Power. London: Longman.

Fairclough, N. (1992). Discourse and Social Change. Cambridge: Polity Press.

Fairclough, N. (1995a). Media Discourse. London: Arnold.

Fairclough, N. (1995b). Critical Discourse Analysis: The Critical Study of Language. London: Longman.

Fairclough, N. (2003). Analysing Discourse: Textual Analysis for Social Research. London: Routledge.

Fowler, R. (1985). Power. In Van Dijk, T. A. (Ed). Handbook of Discourse Analysis, 4, pp.61-83. London: Academic Press.

Goatly, A. (2000). An Introduction Coursebook: Critical Reading and Writing. London: Routledge.

Goldman, R. (1992). Reading Ads Socially. London: Routledge.

Gorn, G.J., Chattopadhyay, A., Yi, T., \& Dahl, D.W. (1997). 'Effects of color as an executional cue in advertising: They're in the shade'. Management of Science 43, pp. 1387-1400. http://dx.doi.org/10.1287/mnsc.43.10.1387

Hall, S.; Whannel, P. (1964). The Popular Arts. London: Hutchinson. 
Halliday, M. (1994). An introduction to functional grammer.2 nd edition, London: Edward Arnold.

Halliday, M.A.K. \& Hasan, R. (1976). Cohesion in English. New York: Longman.

Hasan, R. (1984). The texture of text. In Graddol, D. \& Boyd-Barret, O.(Eds), Texts: Authors and Readers of Media, pp. 162-79. Clevedon: Multilingual Matters.

Hoey, M. (1991). Patterns of Lexis in Text. Oxford: Oxford University Press.

Jefkins, F. (1994). Advertising. London: Pitman.

Jewit, C \& Oyama, R. (2001). Visual meaning: a social semiotic approach. in van Leeuwen, T. \& Jewit, C. (Eds.), Handbook of visual meaning. Chapter7, p.134. Sage. [Online] Available: http:// www. books. google.com/ books? Id=DKqW4aAnIBAG.

Kress, G. \& Hodge, R. (1979/1988). Language as ideology. London: Routledge and Kegan Paul.

Kress, G. \& Van Leeuwen, T. (1996). Front Pages: The critical analysis of newspaper layout', in Approaches to Media Discourse, (Ed.) Bell, A. \& Garrett, P. Chapter 7. Oxford: Blackwell Publishers.

Kress, G. (2010). Multimodality: A Social Semiotic Approach to Contemporary Communication. London: Routlege.

Kress, G., \& van Leeuwen, T. (2006). Reading Images. The Grammar of Visual Design. 2 nd edition. London: Routledge.

Lennon, P. (2004). Allusions in the Press: an Applied Linguistic Study. Berlin: Walter de Gruyter. http://dx.doi.org/10.1515/9783110197334.

Lester, P.M. (2000). Visual Communication - Images with Messages. Belmont: Wadswoth/ Thomson Learning.

Machin, D. (2004). Two Computer War Games Set in Lebanon: The influence of a global technology on discourse, unpublished paper, Cardiff University.

Maliszewski, J. (2010). Diskurse Und Terminologie Beim Fachbersetzen Und Dolmestshen/ Discourse and Terminology in Specialist Translation and Interpretating. London: Peter Lang.

Martin, J.R. (1985). Factual writing. Geelong: Deakin University Press.

Meinhof, U. (2004). Reading S: from the street to the screen breadline Britain and the semiotics of poverty. In Yates, S. J. \& Yates, S. (Eds.), Doing Social Science Research, p.263. London: Sage. [Online] Available: http:// www. books. google.com/ books? id=Ct2Sy4H4Hz8C.

Morris, J., \& Hirst, G. (1991). Lexical cohesion computed by the saural relations as an indicator of the structure of text. Computational Linguistics, 17, pp. 21-48.

Najafian, M (2010). Print advertising and Globalization: a Critical approach. Proceeding of the First International Conference on Translation and Interpretation, Bagkok, 1-3 November 
2010, pp.123-133. Thiland: The Chalermprakiat Center of Translation and Interpretation Faculty of Arts, Chulalongkorn University.

Najafian, M. \& Ketabi, S. (2011). Advertising Social Semiotic Representation: A Critical Approach, International Journal of Industrial Marketing, 1(1). [Online] Available: http:// www. macrothink.org.

Poynton, C. (1985). Language and Gender: Making the Difference. Geelong: Deakin University Press.

Rowse, E. J., Fish, L. J. (2005). Fundamentals of Advertising. USA: Kassinger Publishing.

Saren, M. \& Maclaran, P. \& Goulding, C. \& Elliott, R. \& Shankar, A. and Catterall, M. (Eds) (2007). Critical Marketing. Defining the Field. Oxford: Elsevier.

Scollon, R. \& Scollon, S. W. (2003). Discourse in Place: Language in the Material World. London/New York: Routledge. http://dx.doi.org/10.4324/9780203422724

Simpson, P. \& Mayr, A. (2010). Language and Power. London: Routledge. Time, January 8th 2000 - October 15th 2001, www.timeeurope.com

Tom, G., T. Barnett, W. Lew, \& Selmants, J. (1987). Cueing the consumer: the role of salient cues in consumer perception, Journal of Consumer Marketing, 4(2), pp. 23-27. http://dx.doi.org/10.1108/eb008193

Van Dijk, T. A. (ed.) (1995). Discourse as Structure and Process. London: Sage.

Van Leeuwen, T. (2005). Introducing Social Semiotics. London/New York: Routledge.

Walters, J., Apter, M. J., \& Svebak, S. (1982). Color preference arousal, and the Theory of psychological reversals. Journal of Motivation and Emotion, 6(3), pp. 193-215. http://dx.doi.org/10.1007/BF00992245.

Widdowson, H. (1978) Teaching Language as Communication. Oxford: Oxford University Press.

Williamson, J. (1978). Decoding Advertisements: Ideology and Meaning in Advertising. London: Marion Boyars. 


\section{Macrothink}

International Journal of Linguistics ISSN 1948-5425

\section{JAMES \\ BOND'S CHOICE

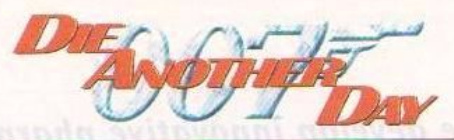

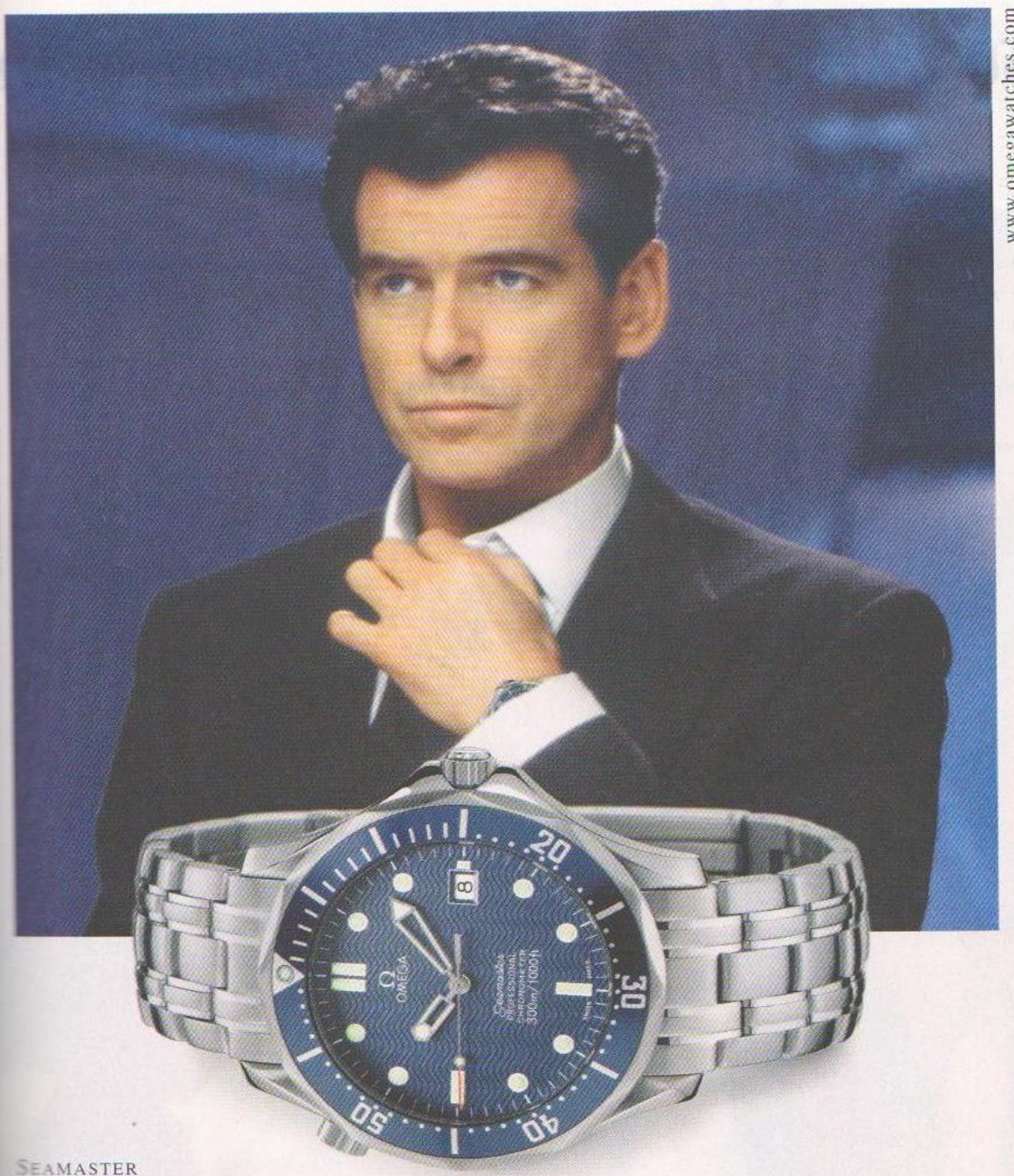

Bond. James Bond. This typically suave greeting by everybody's fwrourite secret agent is arguably one of the most easily recognised tres in cinematographic history. Omega has built up a lasting (and Iffe-saving) relationship with secret agent 007 and is proud to be acod's choice once again in "Die Another Day".

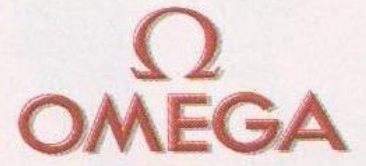

Figure 1. The advertisement of 'OMEGA' watch extracted from 'Time' magazine (2000) 


\section{The OMEGA Co-Axial Escapement A Revolution in Master Watchmaking}
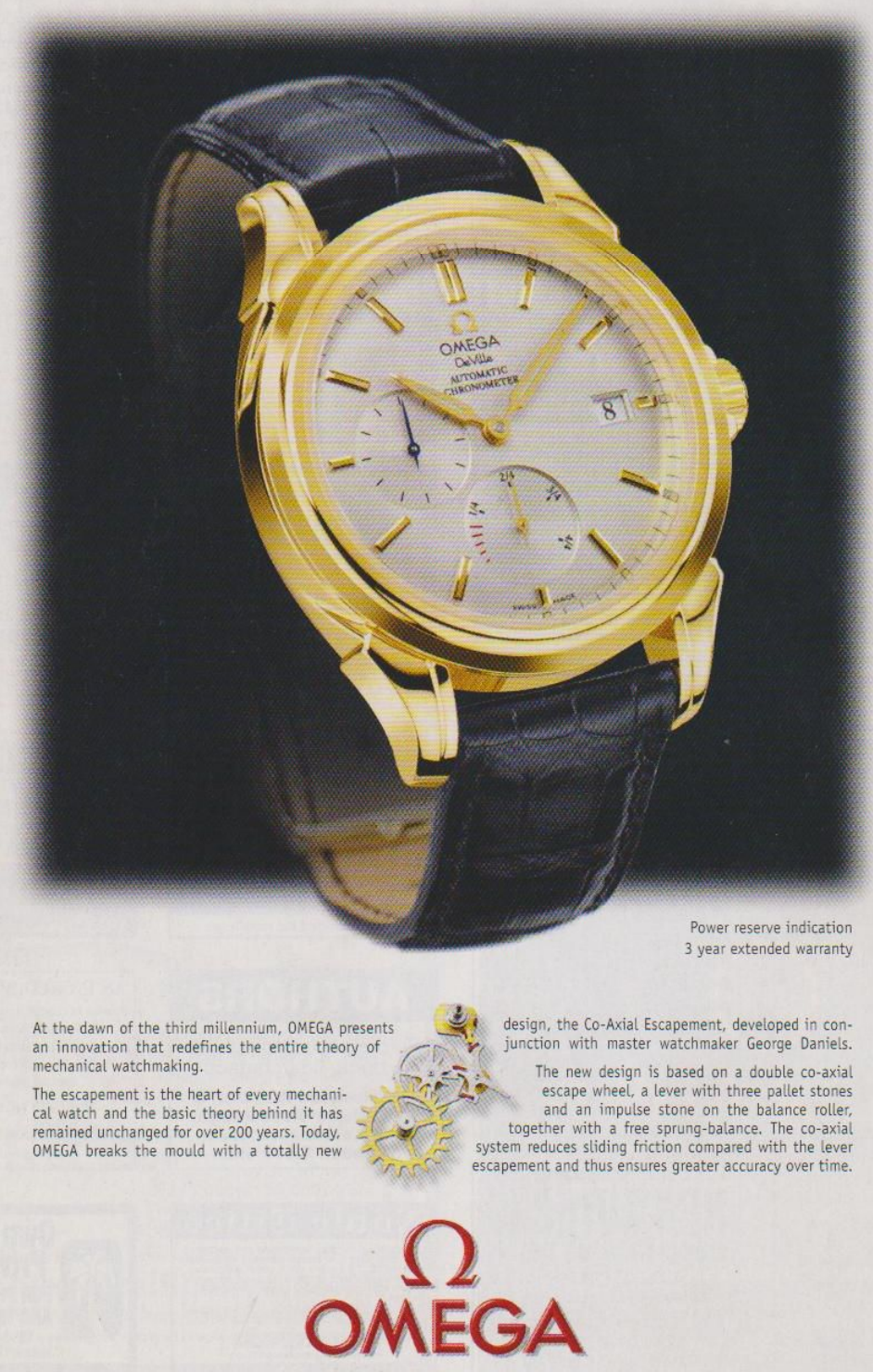

www.omegawatches.com

Figure 2. The advertisement of 'OMEGA' watch extracted from 'Time' magazine (2001) 